Int. J. Electrochem. Sci., 15 (2020) 12252 - 12263

International Journal of

ELECTROCHEMICAL

SCIENCE

$\underline{\text { WWW.electrochemsci.org }}$

\title{
Promotion of Oxygen Reduction to Hydrogen Peroxide by Ammonium Ions on $\mathrm{N}$-doped Carbon Catalyst
}

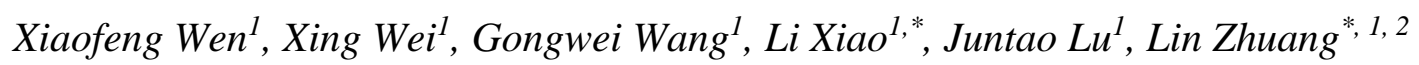 \\ ${ }^{1}$ College of Chemistry and Molecular Sciences, Hubei Key Lab of Electrochemical Power Sources, \\ Wuhan University, Wuhan 430072, China \\ ${ }^{2}$ The Institute for Advanced Studies, Wuhan University, Wuhan 430072, China \\ "E-mail: chem.lily@whu.edu.cn, lzhuang@whu.edu.cn
}

doi: $10.20964 / 2020.12 .46$

Received: 2 August 2020 / Accepted: 23 September 2020 / Published: 31 October 2020

\begin{abstract}
A lot of efforts have been devoted to the improvement of the catalytic activity and hydrogen peroxide $\left(\mathrm{H}_{2} \mathrm{O}_{2}\right)$ selectivity of the catalysts in two-electron oxygen reduction reaction (ORR) utilized for production of $\mathrm{H}_{2} \mathrm{O}_{2}$. Little attention has been paid to the influence of the electrolyte itself. Herein, we report that the two-electron ORR catalytic performance of the catalyst strongly depends on the cations of the electrolyte. The catalytic performance of an N-doped carbon (PNC) catalyst has been evaluated in two different aqueous electrolytes: $\left(\mathrm{NH}_{4}\right)_{2} \mathrm{SO}_{4}$ and $\mathrm{Na}_{2} \mathrm{SO}_{4}$. The results show that the ORR catalytic activity and the $\mathrm{H}_{2} \mathrm{O}_{2}$ selectivity in $\left(\mathrm{NH}_{4}\right)_{2} \mathrm{SO}_{4}$ solution are much better than that in $\mathrm{Na}_{2} \mathrm{SO}_{4}$ solution, namely with $\mathrm{H}_{2} \mathrm{O}_{2} \mathrm{FE}$ of $90.2 \%$ and current density of $13.9 \mathrm{~mA} \mathrm{~cm}^{-2}$ in $\left(\mathrm{NH}_{4}\right)_{2} \mathrm{SO}_{4}$ compared to $67.8 \%$ and $2.5 \mathrm{~mA} \mathrm{~cm}^{-2}$ in $\mathrm{Na}_{2} \mathrm{SO}_{4}$. The in-situ Fourier transform infrared (FTIR) spectroscopy shows that $\mathrm{H}_{2} \mathrm{O}$ acts in the reaction in $\mathrm{Na}_{2} \mathrm{SO}_{4}$ solution as a proton source, but there was no evidence of the same role of $\mathrm{H}_{2} \mathrm{O}$ in $\left(\mathrm{NH}_{4}\right)_{2} \mathrm{SO}_{4}$ solution. Further experimental results also show that the ORR performance of PNC is dependent on the concentration of $\left(\mathrm{NH}_{4}\right)_{2} \mathrm{SO}_{4}$ solution, but independent on the concentration of $\mathrm{Na}_{2} \mathrm{SO}_{4}$ solution. Thus, we reasonably infer that ammonium ions have promoted the ORR catalytic performance of PNC.
\end{abstract}

Keywords: oxygen reduction reaction, hydrogen peroxide, faradaic efficiency, electrocatalysis, ATRFTIR

\section{FULL TEXT}

(C) 2020 The Authors. Published by ESG (www.electrochemsci.org). This article is an open access article distributed under the terms and conditions of the Creative Commons Attribution license (http://creativecommons.org/licenses/by/4.0/). 